\title{
The use of methotrexate in dermatology
}

\author{
Jagoda BALABAN \\ Clinic of Dermatovenereology, University Clinical Center Banjaluka, Bosnia and Herzegovina \\ Correspondence: Jagoda Balaban, E-mail: jagoda.balaban@yahoo.com
}

UDC 616.5-085:615.27.03

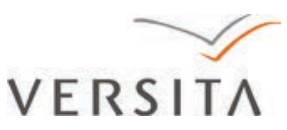

\begin{abstract}
Methotrexate is a cytotoxic antimetabolite agent and a folic acid antagonist. Except for its use in oncology and rheumatology, it is widely used in dermatology. The most important indications include severe forms of psoriasis, but also a wide range of autoimmune diseases and dermatoses with different etiology and pathophysiology such as: bullous pemphigoid, dermatomyositis, pityriasis rubra pilaris, sarcoidosis, T-cell lymphomas, Behcet's disease, adult atopic eczema, scleroderma, Reiter's syndrome and many others. For dermatological indications methotrexate is usually taken in low oral doses, 5-25 mg once a week. In certain diseases it can be applied to the lesion itself, or in the form of local preparations. Considering the fact that numerous drugs affect various metabolic phases of methotrexate and may increase its toxicity, it is of utmost importance to consider other prescribed drugs, especially certain antibiotics, nonsteroidal antiinflammatory drugs, antiepileptic drugs, retinoids, proton pump inhibitors and so on. If the selection of patients is correct, if drugs are taken regularly and laboratory monitoring is included, methotrexate is a truly efficient and safe drug that can be taken for months or years if necessary.
\end{abstract}

\section{Key words}

Methotrexate + administration and dosage + adverse effects + pharmacokinetics + therapeutic use + toxicity; Skin Diseases + drug therapy; Dermatology; Dermatologic Agents

$\mathrm{M}$ ethotrexate (MTX) is a cytostatic drug from the group of antimebolites, analogous to folic acid. It is not only used to treat severe cases of psoriasis, but also a wide range of autoimmune diseases. Analogous to folic acid, MTX inhibits enzyme dihydrofolatereductase, thus decreasing the levels of synthesis of purine basis, nucleic acids and some amino acids. Low oral doses of up to $25 \mathrm{mg}$, once per week, are often used in dermatology. After oral intake of these doses of MTX, maximal blood concentration is achieved in 45 minutes to 2 hours time. It is accumulated in erythrocytes by reverse protein binging and hepatocytes. It is mostly excreted through kidneys by glomerular filtration (up to $70 \%$ ), and less by tubular secretion via bile and feces. Pharmacokinetics of the drug is also associated with the age of the patient, increasing the distribution and elimination of the drug as the age decreases (1-2).

\section{Interactions with other drugs}

Various drugs affect and modify the metabolic phase of MTX. Some antibiotics (neomycin) and retinoids (etretinate) modify the resorption and increase the hepatotoxicity of the drug. Certain drugs: phenytoin, barbiturates, tetracyclines, phenylbutazone, salicylates, trimethoprim-sulfamethoxazole suppress MTX binding to plasma proteins and increase the amount of free, biologically active drug in the blood, thus increasing the risk of hematologic toxicity. Other drugs, like nesteroidal antiinflammatory drugs, salicylates, and sulphonamides increase the half-life of biologically active MTX. Cyclosporine reduces the renal clearans of MTX. Dipyridamole leads to prolonged activity of MTX due to intracellular accumulation. Drugs that affect the metabolism of folic acid, like phenytoin can increase the toxicity of MTX as well $(4,5)$. 


\section{Administration of methotrexate}

In dermatological indications, MTX can be taken either in one dose or in multiple doses at 12 hour intervals. Usually, patients begin with a test dose 2.5$5 \mathrm{mg}$; after the initial phase, patients are given 10-15 mg per week, with an increase of the dose from 2.5 $\mathrm{mg}$ to $5 \mathrm{mg}$ per week over the next few weeks, when full therapeutic effect is expected. After achieving the therapeutic effect, the dose is lowered by $2.5-5 \mathrm{mg}$ per week, till the lowest effective dose. MTX treatment takes a long time and oral therapy is conducted in hospitals. It is crucial for patients to be well acquainted with the characteristics of the drug, and it is necessary to inform their dermatologist or family doctors about possible changes healthwise. That includes the potential toxic effects of the drug (6).

\section{Choice of patients and intake monitoring}

In regard to anamnestic data and laboratory diagnostics, it is necessary to exclude patients who should not take the drug. Anemia, thrombocytopenia and leukopenia are contra-indicatios for the therapy, as well as infections, peptic ulcers, ulcerative colitis, alcoholism, immunodeficiency, pregnancy, lactation. Before the initiation of the therapy, all patients need to obtain: erythrocyte sedimentation rate (ESR), complete blood count, transaminases (AST, ALT, gamma GT, AP), urea, creatinine, urine. Patients with liver diseases need to examine anti-HIV antibodies, hepatitis-B antigens and HCV RNA. During first three months of therapy erythrocytes, leukocytes and thrombocytes need to be controlled once per week, a day before taking the next dose of drug. Later on, if there are no side effects, laboratory tests are done less often. During the first three months of therapy, biochemical tests are regularly done once per month, and later on, every three months. Biochemical tests are done more often in cases with significant pathological transaminase levels, or if other hepatotoxic drugs are taken simultaneously $(2,7)$.

Due to interactions of MTX with other drugs and the necessity for their intake, as well as because of necessary dose calculations, patients are advised to fill the evidence chart for MTX which is used by Clinical Center Banjaluka since 2001 (Figure 1). Patients note the taken weekly dose, so it is easy to calculate the total monthly and annual intake. The chart consists of a list of drugs whose intake may be potentially dangerous when taken at the same time as MTX, as well as the intake manner, and laboratory monitoring data.

\section{Side effects}

Side effects of MTX include gastrointestinal toxicity, hepatotoxicity, and hematological toxity. Nausea is the main symptom of digestive tract disease which is observed in approximately one quarter of patients. It is managed by lowering the dose or by changing the manner of drug intake. Diarrhea and anorexia are observed less often. Hepatotoxicity can be either acute or chronic. Acute hepatotoxicity is mostly transitory, while chronic can be observed when high doses are taken. About $10-20 \%$ of patients exhibit fibrosis and $6-10 \%$ exhibit liver cirrhosis. The above-mentioned complications call for immediate termination of MTX therapy. Recent literature data suggest that MTX hepatoxicity is less than it was previously thought however diabetes and obesity are significant factors for liver damage (8). Most often observed hematological complications include megaloblastic anemia, rarely leukopenia and thrombocytopenia. If the leukocyte count is less than $3000 / \mathrm{mm}^{3}$, or thrombocyte count is less than $100000 \mathrm{~mm}^{3}$, the therapy should be terminated for a period of time. If the levels are stabilized during the next week, therapy continues, usually with lower intake. About 2-19\% of patients exhibit coutaneous or mucosal erosions which calls for immediate termination of MTX therapy. Less often, patients exhibit urticaria, acral erythema, anagen alopecia. Rarely, side effects affect the respiratory system as pneumonia and fibrosis. Lung fibrosis is another indication for MTX therapy termination (79).

\section{Liver biopsy and cumulative dose of methotrexate} There are still controversies regarding liver biopsy during long term MTX therapy. Today, it is generally accepted that if a patient does not exhibit risk factors for liver diseases and if laboratory analysis shows that the liver function is within acceptable limits, biopsy should be done after cumulative dose of $4 \mathrm{~g}$. Previosly, the limit was thought to be much lower, $1.5 \mathrm{~g}$. Patients who exhibit liver disease risk factors should undergo biopsy after two to four months of therapy, and the second one after cumulative dose of 1.5 g. (10). 


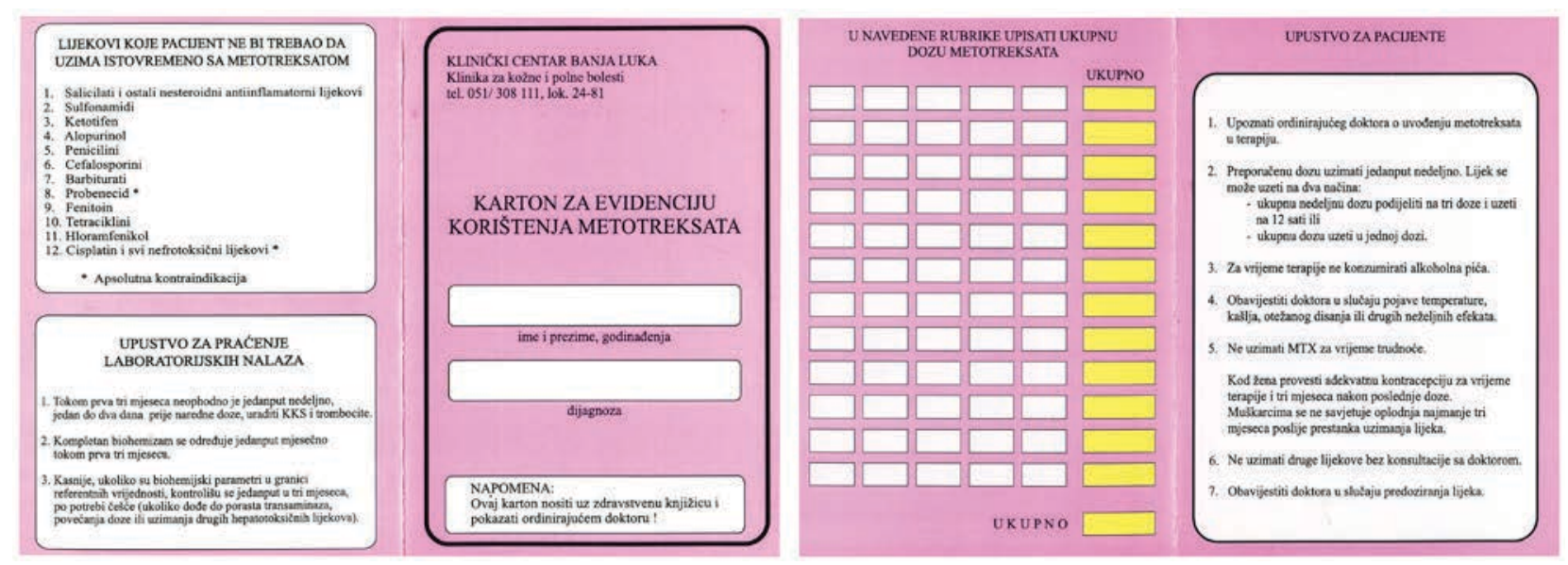

Figure 1. Evidence chart for methotrexate

\section{Methotrexate and folic acid}

It is generally thought that hepatotoxic effects of MTX (oral dose of 5-30 mg) can be prevented by intake of folic acid for almost all indications. Previosly, the usual oral dose of folic acid was 5-10 mg per day, at least two days after MTX intake; however, some authors think that it should be taken every day, except for the days when methotrexate is taken. Today, $5 \mathrm{mg}$ of folic acid is usually given a day after taking MTX. If acute side effects of methotrexate occur, it is advised to take active folic acid (11-14).

\section{Indications for methotrexate}

\section{Psoriasis}

In dermatology, MTX is usually used to treat psoriasis. Most often psoriasis is exhibited in sever cases of: erythrodermia, psoriatic arthropathy, pustular psoriasis and some forms of plaque psoriasis. Psoriatic erythoderma is a severe, generalized form of psoriasis where $90 \%$ of skin is covered with erythema, infiltrations and scaling. Considering the fact that inflammation of a high percentage of skin can significantly influence thermoregulation, hemodynamics, metabolism of water and proteins, intestinal absorption, these patients have not only skin changes, especially in acute forms of the disease, but also significant disorders of general wellbeing and febrility. Psoriatic arthropathy is a simultaneous occurrence of psoriasis vulgaris and of polyarthritic joint changes, particulary on the distal joints (fingers and toes). Joint changes manifest as distal psoriatic arthritis, mutilating psoriatic arthritis, psoriatic polyarthritis, ankylosing spondylitis. Severe forms may lead to joint deformations, as well as invalidity. Pustular psoriasis is a form of psoriasis that is clinically manifested by eruptions of erythema and sterile pustules. Changes can be both local and general. The general form is a severe form of the disease accompanied by fever and changes in well-being. Methotrexate is also used in the treatment of chronic, resistant plaque forms of psoriasis vulgaris which cover more than $50 \%$ of the skin. It is also efficient in treating nail psoriasis (psoriasis unguium). Regular doses of MTX in psoriatic patients are from 7.5 to $20 \mathrm{mg}$ per week (5-19).

In around $80 \%$ of psoriatic patients effects of methotrexate are satisfactory, and full remission is noticed in around $60 \%$ of patients. Usually, noticeable improvement is achieved within two to three weeks of therapy, and full effect is achieved in eight weeks. The obtained treatment effects are maintained by lowest dosage of the drug that can be taken for months, sometimes even years. If the treatment is terminated, there is no rebound phenomenon. That means that the overall psoriatic condition is worsened (2). MTX today also has a place in the treatment of psoriasis in children (20,21). Local methotrexate is used efficiently in treating certain forms of psoriasis, in the form of $0.25 \%$ and $1 \%$ hydrophilic gel (22).

\section{Bullous dermatoses}

MTX is used to treat autoimmune bullous dermatoses, usually bullous pemphigoid. Clinically, it manifests with erythema, large or small blisters and 
itching. Around $25 \%$ of patients have mouth mucosal erosions. The disease mainly occurs in the elderly. Adequate therapeutic effects can be achieved by using low doses of MTX, 5-10 mg per week. Methotrexate is less often used in treating pemphigus. It is used for generalized, persistent forms of benign familial pemphigus (Hailey-Hailey disease) $(23,24)$.

\section{Dermatomyositis}

Dermatomyositis is an autoimmune, systemic disease of connective tissues, manifesting with idiopathic, inflammatory myopathy (symmetric weakness and pain in shoulder muscles, neck, hands, esophagus). The skin exhibits noticeable pathognomonic papules (Gottron), livid periorbital edema and erythema, telangiectasas around the nail, and severe maculopapullar rash. Systemic manifestations include: general weakness, gastrointestinal symptoms, as well as joints, heart and lungs complications. MTX in doses from $25-50 \mathrm{mg}$ per week is used to treat dermatomyositis resistant to corticosteroid therapy (25).

\section{Discoid lupus erythematosus}

It is a chronic skin disease that usually manifests in photo exposed regions of the skin. The main symptoms of the disease are: hyper- and hypopigmentation, telangiectasias and atrophy. Its manifestations include a number of clinical variations. MTX is used as adjuvant therapy, mostly when the disease is resistant to standard therapy (26).

\section{Pityriasis rubra pilaris}

It is a hereditary or acquired chronic disease manifested by more or less circumscribed keratotic papules, palmoplantar yellowish keratoderma, rearly with erythroderma. It may appear as a classical or atypical form in adults as well as in children. Most patients achieve remission by using low doses of MTX, 5-10 mg per week, for a few months (27).

\section{Sarcoidosis}

Sarcoidosis is a granulomatous multisystemic disease of unknown etiology. Cutaneus sarcoidosisis is usually manifested by skin changes: erythema nodosum, papular, plaque or nodular type, as well as by a wide range of atypical forms. For treating chronic forms MTX is used 15-20 mg per week for six to eight weeks (28).

\section{Keratoacanthoma}

Keratoacanthoma is a rapidly growing epidermal skin tumor composed of keratinizing squamous cells originating from pilosebaceous follicles and resolving spontaneously untreated. A typical keratoacanthoma shows raised margins and a central keratin-filled crater. Apart from the typical form, there are also a number of atypical forms: giant, centrifugum marginatum, eruptive. Some forms of keratoacanthoma, like centrifugum marginatum, can be treated successfully by intralesional application of MTX (29).

\section{Reiter's syndrome}

Reiter's syndrome is a multisystemic disease which is preceded by enteric or genitourinary, infection, continued by arthritis, eye lesions and various skin changes, mostly hyperkeratotic plantar plaques and penile lesions. Sever chronic diseases, resistant to nonsteroidal antiinflammatory agents and conventional therapy are treated with MTX in doses from 7.5-15 mg per week (30).

\section{T-cell lymphomas}

Epidermal T-cell lymphomas (mycosis fungoides, Sezary syndrome, pagetoid reticulosis) are a group of rare, highly malignant T-cell lymphomas, in which the skin is the primary selection of malignant T-cell clone. In regular practice, mycosis fungoides is mostly encountered. MTX administration regimen is used in stage III lymphomas (TNM staging T-cellular lymphoma) as mono-therapy or in combination with other therapy modalities $(31,32)$.

\section{Behçet's disease}

Behçet's disease is a multi-systemic inflammation of small blood vessels, mostly veins. It is manifested by recurrent oral and genital ulcerations, skin changes shuch as erythema nodosum, pseudofolliculitis, pustules and eye lesions. Considering the fact that any blood vessel can be affected by inflammation, patients can have different systemic manifestations, mostly in joints, gastrointestinal tract or in the central nervous system. MTX is an adjuvant therapy given in doses from 7.5-15 mg per week (33).

\section{Atopic eczema}

Atopic eczema (dermatitis) is a chronic, inflammatory, itchy skin disease that is mostly found in children, but 
can persist or manifest for the first time in adulthood as well. Apart from allergic rhinitis and asthma, it is one of the four most common atopic diseases. Lately, more and more researches have shown positive effects of low doses of MTX in treating average to severe, refractory variations of atopic eczema in adults (34, 35).

\section{Localized scleroderma (Morphea)}

Localized scleroderma is a connective tissue desorder of unknown etiology characterized by skin fibrosis. The condition has various clinical forms: circumscript plaques ("en plaque“), linear („en bande“), frontoparietal lesions („en coup de sabre") or generalized morphea. MTX is used in the treatment of all forms of localized scleroderma in adults and in children, usually in combination with systemic corticosteroids. It is given in doses $15-20 \mathrm{mg}$ per week $(36,37)$.

\section{Other indications}

In the last few years, there has been an increasing amount of research supporting successful use of methotrexate in treating various skin diseases: universal and total alopecia areata, erosive vulvovaginal lichen planus, parthenium dermatitis (a form of allergic contact dermatitis found mainly in India and Australia on the plants of the Compositae family), reticulohistiocytosis, resistant acute varioliform lichenoid pityriasis (38-41).

\section{Abbreviations}

MTX - Methotrexate
ESR - Erythrocyte sedimentation rate
AST - Aspartate aminotransferase
AP - alkaline phosphatase
HIV - Human immunodeficiency virus
HCV - Hepatitis C virus
RNA - Ribonucleic acid
ALT - Alanine aminotransferase
gamma GT - gamma glutamyl
transpeptidase

\section{References}

1. Bangert CA, Costner MI. Methotrexate in dermatology. Dermatol Ther 2007;20(4): 216-28.

2. Milojević M. Citotoksična sredstva. U: Karadaglić Đ.
Dermatologija. Beograd: Vojnoizdavački zavod; 2000. str. 22516.

3. Barker J, Horn EJ, Lebwohl M, Warren RB,Nast A, Rosenberg $\mathrm{W}$, et al. Assessment and management of methotrexate hepatotoxicity in psoriasis patients: report from a consensus conference to evaluate current practice and identify key questions toward optimizing methotrexate use in the clinic. J Eur Acad Dermatol Venereol 2011;25(7):758-64.

4. Katchamart W, Trudeau J, Phumethum V, Bombardier C. Efficacy and toxicity of methotrexate (MTX) monotherapy versus MTX combination therapy with non-biological diseasemodifying antirheumatic drugs in rheumatoid arthritis: a systematic review and meta-analysis. Ann Rheum Dis 2009;68(7):1105-12.

5. Hider SL, Bruce IN, Thomson W. The pharmacogenetics of methotrexate. Rheumatology 2007;46(10):1520-4.

6. Suzuki K, Doki K, Homma M, Tamaki H, Hori S, Ohtani $\mathrm{H}$, et al. Co-administration of proton pump inhibitors delays elimination of plasma methotrexate in high-dose methotrexate therapy. Br J Clin Pharmacol 2009;67(1):44-9.

7. Lindsay K, Fraser AD, Layton A, Goodfield M, Gruss H, Gough A. Liver fibrosis in patients with psoriasis and psoriatic arthritis on long-term, high cumulative dose methotrexate therapy. Rheumatology 2009;48(5):569-72.

8. Berends MA, Snoek J, de Jong EM, van de Kerkhof PC, van Oijen MG, van Krieken JH, et al. Liver injury in long-term methotrexate treatment in psoriasis is relatively infrequent. Aliment Pharmacol Ther 2006;24(5):805-11.

9. Carneiro SC, Cássia FF, Lamy F, Chagas VL, Ramos-e-Silva M. Methotrexate and liver function: a study of 13 psoriasis cases treated with different cumulative dosages. J Eur Acad Dermatol Venereol 2008;22(1):25-9.

10. Thomas JA, Aithal GP. Monitoring liver function during methotrexate therapy for psoriasis: are routine biopsies really necessary? Am J Clin Dermatol 2005;6(6):357-63.

11. Prey S, Paul C. Effect of folic or folinic acid supplementation on methotrexate-associated safety and efficacy in inflammatory disease: a systematic review. Br J Dermatol 2009;160(3):622-8.

12. Strober BE, Menon K. Folate supplementation during methotrexate therapy for patients with psoriasis. J Am Acad Dermatol 2006;55(2):366-7.

13. Kozub P, Simaljakova M. Systemic therapy of psoriasis: methotrexate. Bratisl Lek Listy 2011;112(7):390-4.

14. Morgan SL, Baggott JE. Folate supplementation during methotrexate therapy for rheumatoid arthritis. Clin Exp Rheumatol 2010;28(61):102-9.

15. Haustein UF, Rytter M. Methotrexate in psoriasis: 26 years' experience with low-dose long-term treatment. J Eur Acad Dermatol Venereol 2000;14(5):382-8.

16. Kalb RE, Strober B, Weinstein G, Lebwohl M. Methotrexate and psoriasis: 2009 National Psoriasis Foundation Consensus Conference. J Am Acad Dermatol 2009;60(5):824-37.

17. Menter A, Korman NJ, Elmets CA, Feldman SR, Gelfand JM, Gordon KB, et al. Guidelines of care for the management of psoriasis and psoriatic arthritis. Section 4: Guidelines of care for the management and treatment of psoriasis with traditional systemic agents. J Am Acad Dermatol 2009;61(3):451-85.

18. Chládek J, Simková M, Vanecková J, Hroch M, Chládkova 
J, Martínková J, et al. The effect of folic acid supplementation on the pharmacokinetics and pharmacodynamics of oral methotrexate during the remission-induction period of treatment for moderate-to-severe plaque psoriasis. Eur J Clin Pharmacol 2008;64(4):347-55.

19. Asawanonda P, Nateetongrungsak Y. Methotrexate plus narrowband UVB phototherapy versus narrowband UVB phototherapy alone in the treatment of plaque-type psoriasis: a randomized, placebo-controlled study. J Am Acad Dermatol 2006;54(6):1013-8.

20. Jager ME, Jong EM, Kerkhof PC, Seyger MM. Efficacy and safety of treatments for childhood psoriasis: a systematic literature review. J Am Acad Dermatol 2010;62(6):1013-30.

21. Collin B, Vani A, Ogboli M, Moss C. Methotrexate treatment in 13 children with severe plaque psoriasis. Clin Exp Dermatol 2009;34(3):295-8.

22. Syed TA, Hadi SM, Qureshi ZA, Nordstrom CG, Ali SM. Management of psoriasis vulgaris with methotrexate $0.25 \%$ in a hydrophilic gel: a placebo-controlled, double-blind study. J Cutan Med Surg 2001;5(4):299-302.

23. Patton T, Korman N. Role of methotrexate in the treatment of bullous pemphigoid in the elderly. Drugs Aging 2008;25(8):623-9.

24. Mutasim DF. Autoimmune bullous dermatoses in the elderly: an update on pathophysiology, diagnosis and management. Drugs Aging 2010;27(1):1-19.

25. Marie I. Therapy of polymyositis and dermatomyositis. Presse Med 2011;40(4):257-70.

26. Walling HW, Sontheimer RD. Cutaneous lupus erythematosus: issues in diagnosis and treatment. Am J Clin Dermatol 2009;10(6):365-81.

27. Klein A, Landthaler M, Karrer S. Pityriasis rubra pilaris: a review of diagnosis and treatment. Am J Clin Dermatol 2010;11(3):157-70.

28. Doherty CB, Rosen T. Evidence-based therapy for cutaneous sarcoidosis. Drugs 2008;68(10):1361-83.

29. Krunić A. Keratoakantom. U: Karadaglić Đ. Dermatologija. Beograd: Vojnoizdavački zavod; 2000. str. 834-41.

30. Graham RM. Reiter's disease. In: Rook A, Wilkinson DS,

Ebling FJG, Champion RH, Burton JL, editors. Textbook of dermatology. $5^{\text {th }}$ ed. Oxford: Blackwell Scientific Publications; 1992. p. 2455-67.

31. Mestel DS, Beyer M, Steinhoff M, Sterry W,Assaf C.The treatment of mycosis fungoides. Ital Dermatol Venereol 2008;143(6):395-408.

32. Whittaker SJ, Foss FM. Efficacy and tolerability of currently available therapies for the mycosis fungoides and Sezary syndrome variants of cutaneous T-cell lymphoma. Cancer Treat Rev 2007;33(2):146-60.

33. Yazici H, Fresko I, Yurdakul S. Behçet's syndrome: disease manifestations, management, and advances in treatment. Nat Clin Pract Rheumatol 2007;3(3):148-55.

34. Zoller L, Ramon M, Bergman R. Low dose methotrexate therapy is effective in late-onset atopic dermatitis and idiopathic eczema. Isr Med Assoc J 2008;10(6):413-4.

35. Weatherhead SC, Wahie S, Reynolds NJ, Meggitt SJ. An open-label, dose-ranging study of methotrexate for moderate-tosevere adult atopic eczema. Br J Dermatol 2007;156(2):346-51. 36. Beltramelli M, Vercellesi P, Frasin A, Gelmetti C, Corona F. Localized severe scleroderma: a retrospective study of 26 pediatric patients. Pediatr Dermatol 2010;27(5):476-80.

37. Kroft EB, Creemers MC, van den Hoogen FH, Boezeman JB, de Jong EM. Effectiveness, side-effects and period of remission after treatment with methotrexate in localized scleroderma and related sclerotic skin diseases: an inception cohort study. $\mathrm{Br} \mathrm{J}$ Dermatol 2009;160(5):1075-82.

38. Jang N, Fischer G. Treatment of erosive vulvovaginal lichen planus with methotrexate. Australas J Dermatol 2008;49(4):2169.

39. Sharma VK, Bhat R, Sethuraman G, Manchanda Y. Treatment of parthenium dermatitis with methotrexate. Contact Dermatitis 2007;57(2):118-9.

40. Kaçar N, Tasli L, Argenziano G, Demirkan N. Reticulohistiocytosis: different dermatoscopic faces and a good response to methotrexate treatment. Clin Exp Dermatol 2010;35(4):120-2.

41. Lazaridou E, Fotiadou C, Tsorova C, Trachana M, Trigoni A, Patsatsi A, et al. Resistant pityriasis lichenoides et varioliformis acuta in a 3-year-old boy: successful treatment with methotrexate. Int J Dermatol 2010;49(2):215-7.

\section{Upotreba metotreksata u dermatologiji}

\section{Sažetak}

Uvod: Metotreksat (MTX) je citoksični lek iz grupe antimetabolita, antagonist folne kiseline. Osim u onkologiji i reumatologiji, široko se upotrebljava i u dermatologiji.

Najznačajnije indijacije su teži oblici psorijaze, ali se $s$ uspehom koristi kod niza drugih, etiološki i patogenetski različitih dermatoza: buloznog pemfigoida, dermatomiozitisa, pitirijaze rubre pilaris, sarkoidoze, T-ćelijskih limfoma, Behčetove bolesti, adultnog atopijskog ekcema, sklerodermije, Rajterovog sindroma i mnogih drugih.

Kod dermatoloških indikacija metotreksat se obično uzima u niskim, oralnim dozama, 5-25 mg jedanput sedmično. Nakon oralne primene ovih doza MTX maksimalna koncentracija u krvi se postiže od 45 minuta do dva sat. Farmakokinetika leka je vezana i za starost pacijenta, tako da je kod mlađih osoba veća distribucija i eliminacija leka nego kod starijih. Kod 
nekih oboljenja se može primeniti intraleziono ili u vidu lokalnog pripravka.

Neželjena dejstva: Najčešće neželjene reakcije MTX su od strane digestivnog trakta, hepatotoksičnost i hematološki poremećaji. Dijabetes i gojaznost su signifikantni rizični faktori za oštećenje jetre. Od hematoloških poremećaja najčešće se javlja megaloblastna anemija, ređe leukopenija i trombocitopenija. Ukoliko broj leukocita padne ispod $3000 / \mathrm{mm}^{3}$ ili broj trombocita ispod $100000 / \mathrm{mm}^{3}$ lečenje se privremeno prekida. Ukoliko se vrednosti normalizuju tokom naredne nedelje, lečenje se može nastaviti, najčešće nižom dozom. U oko 2-19\% lečenih mogu se javiti erozije na koži ili sluzokoži, što zahteva prekid terapije MTX. Ređe se mogu javiti: urtikarija, akralni eritem, alopecija. Neželjene reakcije se rijetko javljaju i od strane respiratornog sistema u vidu pneumopatija i fibroze. Fibroza pluća je takođe indikacija za prekid terapije MTX.

Kumulativna doza MTX i punkciona biopsija jetre : Sve više je pristalica koji smatraju da ukoliko bolesnik nema faktore rizika za oboljenja jetre i ukoliko ima laboratorijske analize u granici referentnih vrednosti, biopsiju treba uraditi nakon kumulativne doze od $4 \mathrm{~g}$. MTX i folna kiselina: Danas se obično daje $5 \mathrm{mg}$ folne kiseline, dan nakon uzimanja MTX. Ukoliko se jave akutni neželjeni efekti metotreksata savjetuje se primjena ampuliranog oblika fiziološki aktivne forme folne kiseline.

Interakcije: $\mathrm{S}$ obzirom da određeni lekovi utiču na različite metaboličke faze metotreksata i mogu povećati njegovo toksično dejstvo, neophodno je voditi računa o istovremenom propisivanju drugih lekova. To se pre svega odnosi na neke antibiotike, lekove iz grupe nesteroidnih antiinlamatornih lekova, antiepileptike, retinoide, inhibitore protonske pumpe. Lekovi kao što su: fenitoin, barbiturati, tetraciklini, fenilbutazon, salicilati, sulfametoksazol-trimetoprim, potiskuju MTX vezan za proteine plazme i povećavaju količinu slobodnog, biološki aktivnog leka u krvi, a samim tim povećavaju rizik hematološke toksičnosti. Drugi lekovi kao npr. nesteroidni antiinflamatorni lekovi (ketoprofen, fenilbutazon, salicilati), sulfonamidi smanjuju tubularnu sekreciju i renalni klirens, produžavajući poluživot biološki aktivnog MTX. Ciklosporin snižava renalni klirens MTX. Dipiridamol dovodi do produženog djelovanja MTX zbog intracelularne akumulacije. Lekovi koji utiču na metabolizam folne kiseline, kao npr. fenitoin, sulfonamidi, trimetoprim takođe mogu povećati toksičnost MTX.

Dermatološke indikacije: Najznačajnije indikacije su teži oblici psorijaze, ali se $s$ uspehom koristi kod niza drugih, etiološki i patogenetski različitih dermatoza: buloznog pemfigoida, dermatomiozitisa, pitirijaze rubre pilaris, sarkoidoze, T-ćelijskih limfoma, Behčetove bolesti, adultnog atopijskog dermatitisa, sklerodermije, Rajterovog sindroma i mnogih drugih.

Psorijaza: Najčešća dermatološka indikacija zaupotrebu MTX je psorijaza. Uglavnom se radi o težim oblicima bolesti: eritrodermija, atropatska psorijaza, pustulozni oblici, izvjesne forme plak psorijaze (kod kojih je zahvaćeno više od $50 \%$ kože). Efikasan je i u lečenju nokatne psorijaze (psoriasis unguium). Uobičajene doze MTX u lečenju psorijatičnih bolesnika su 7,5-20 mg sedmično. Do vidnog poboljšanja dolazi obično nakon dve do tri nedelje lečenja, a potpuna remisija nakon osam nedjelja. Postignuti terapijski efekat se održava najmanjom efikasnom dozom lijeka koja se može uzimati mesecima, nekada godinama. U slučaju prestanka uzimanja leka (iz bilo kog razloga), ne dolazi do tzv. rebound fenomena, odnosno pogoršanja kliničke slike psorijaze. MTX danas ima aktuelno mesto i u lečenju psorijaze u dječjem uzrastu. Postoji i lokalni pripravak metotreksata koji se $s$ efikasno koristi u lečenju određenih oblika psorijaze u vidu $0,25 \%$ i $1 \%$ hidrofilnog gela.

Bulozna oboljenja: Od autoimunih buloznih dermatoza MTX se najčešće koristi u lečenju buloznog pemfigoida. Zadovoljavajući terapijski efekat kod ovih bolesnika može se postići malim dozama MTX 5-10 mg sedmično. Kod grupe pemfigusa metotreksat se ređe koristi, uglavnom kao ađuvantna terapija. Primjenjuje se u generalizovanim, upornim oblicima benignog familijarnog pemfigusa (Hailey-Haileyjeva bolest).

Dermatomiozitis: Kod slabog odgovora na prednizon MTX i azatioprin su prva linija imunosupresiva u lečenju ove bolesti.

Diskoidni eritemski lupus: MTX je kod ovog oboljenja ađuvantni lek i upotrebljava se uglavnom kod oblika rezistentnih na standardnu terapiju.

Pitirijaza rubra pilaris: Kod većine pacijenata zadovoljavajuća remisija se može postići malim 
dozama MTX (5-10 mg sedmično) u periodu od nekoliko meseci.

Sarkoidoza: U hroničnim oblicima MTX se upotrebljava u dozi 15-20 mg sedmično, 6-8 nedjelja.

Keratoakantom: Kod nekih oblika keratoakantoma, kao što je centrifugum marginatum oblik, s uspehom se koristi intraleziona aplikacija MTX.

Rajterov sindrom: Kod težih, hroničnih oblika oboljenja, rezistentnih na nesteroidnu antiinflamatornu terapiju i konvencionalnu terapiju, lek izbora je MTX u dozi 7,5-15 mg nedeljno.

$\mathrm{T}$ - ćelijski limfomi: U ovu grupu spadaju: mycosis fungoides, Sy. Sezary, reticulosis pagetoides, granulomatozni kutani i grupa retkih, visoko malignih $\mathrm{T}$ ćeliskih limfoma. U dermatološkoj praksi češće od ostalih sreće se mycosis fungoides. Terapija MTX se kod ovih bolesnika najčešće sprovodi u III stadijumu (po TNM staging-u T ćelijskih kutanih limfoma) kao monoterapija ili u kombinaciji sa ostalim terapijskim modalitetima

Behčetova bolest: Kod ove bolesti MTX je ađuvantni lek i može se u izvesnim slučajevima dati 7,5-15 mg sedmično. Atopijski dermatitits: U posljednje vreme sve više je radova koji navode povoljan efekat niskih doza MTX u lečenju umerenih do teških, refrakternih oblika atopijskog dermatitisa kod odraslih osoba .

Morfea: MTX se koristi u lečenju svih oblika cirkumskriptne sklerodermije kod odraslih, ali i kod dece, obično u kombinaciji sa sistemskim kortikosteroidima.

Ostale indikacije: $U$ poslednjih nekoliko godina se $\mathrm{u}$ literaturi mogu naći podaci o uspešnom korišćenju metotreksata u lečenju niza drugih dermatoza kao što su: univerzalna i totalna alopecija, erozivni vulvovaginalni lihen planus, Parthenium dermatitis, retikulohistiocitoza, rezistentni oblik pityriasis lichenoides et varioliformis acuta (36-39).

Zaključak: Ukoliko se napravi pravilan odabir bolesnika, lek uzima pravilno i poštuje preporučeni laboratorijski monitoring, radi se o efikasnom i sigurnom leku koji je može uzimati mesecima i godinama.

\section{Ključne reči}

Metotreksat + primena i doziranje + neželjena dejstva + farmakokinetika + terapijska primena + toksičnost; Kožne bolesti + farmakoterapija; Dermatologija; Dermatološki agensi 